\title{
Near-infrared benzodiazoles as small molecule environmentally-sensitive fluorophores
}

\author{
Fabio de Moliner ${ }^{1}$, Ina Biazruchka ${ }^{2}$, Karolina Konsewicz ${ }^{1}$, Sam Benson ${ }^{1}$, Suraj Singh ${ }^{1}$, Jun-Seok Lee (ه) ${ }^{3}$, \\ Marc Vendrell $(\bowtie)^{1}$ \\ 1 Centre for Inflammation Research, Queen's Medical Research Institute, The University of Edinburgh, Edinburgh EH16 4TJ, UK \\ 2 Molecular Recognition Research Centre, Korea Institute of Science and Technology (KIST) \& Bio-Med Program, \\ KIST-School UST, Seoul 02792, Korea \\ 3 Department of Pharmacology, Korea University College of Medicine, Seoul 02841, Korea
}

(C) The Author(s) 2021. This article is published with open access at link.springer.com and journal.hep.com.cn

\begin{abstract}
The development of fluorophores emitting in the near-infrared spectral window has gained increased attention given their suitable features for biological imaging. In this work, we have optimised a general and straightforward synthetic approach to prepare a small library of near-infrared-emitting C-bridged nitrobenzodiazoles using commercial precursors. C-bridged benzodiazoles have low molecular weight and neutral character as important features that are not common in most nearinfrared dyes. We have investigated their fluorescence response in the presence of a wide array of 60 different biomolecules and identified compound $\mathbf{3 i}$ as a potential chemosensor to discriminate between $\mathrm{Fe}^{2+}$ and $\mathrm{Fe}^{3+}$ ions in aqueous media.
\end{abstract}

Keywords fluorescence, probes, iron, screening, library

\section{Introduction}

The development of chemical structures showing enhanced fluorescence emission upon recognition of molecular analytes is an active area of research in analytical chemistry and molecular imaging [1-5]. In addition to their utility as highly sensitive analytical probes for environmental (e.g., metal ion detection) or biological measurements (e.g., quantification of biomarkers in clinical samples) [6-11], they have been increasingly used to derivatise bioactive molecules (e.g., peptides, proteins, antibodies) and to prepare complex molecular

Received February 23, 2021; accepted June 4, 2021

E-mails: junseoklee@korea.ac.kr (Lee J-S), marc.vendrell@ed.ac.uk (Vendrell M) constructs [12-17]. The resulting architectures combine good selectivity for receptors and/or cells of interest as well as high sensitivity derived from environmentally-sensitive readouts, and have been reported as useful tools for in vivo imaging of specific biological processes or subpopulations of cells [18-24]. Among the different chemical structures employed for the development of fluorescent probes, those with emission wavelengths in the NIR (near-infrared) range (i.e., 650-900 $\mathrm{nm}$ ) have received considerable attention [25-29]. NIR fluorophores benefit from the inherently low autofluorescence of biomolecules and tissues in a biological 'silent' window as well as the minimal toxicity derived from light irradiation at relatively long excitation wavelengths.

Our groups and many others have contributed to the synthesis and characterization of NIR fluorescent structures with very diverse chemical scaffolds (Fig. 1). Some of the most used include Si-rhodamines [30,31], phthalocyanines [32-34], squaraines [35,36], porphyrins [37], tricarbocyanines $[38,39]$, and the recently reported flavylium polymethines with emission wavelengths over 1000 $\mathrm{nm}$ [40]. One common feature of all these NIR-emitting scaffolds is their relatively large hydrophobicity, which can result in limited water solubility (e.g., charged groups such as sulfonates are often needed to enhance solubility in aqueous media) as well as their large molecular size, which can hamper the retention of bioactivity when derivatising peptides and proteins. C-bridged nitrobenzodiazoles have been recently described as chemical structures with relatively small size $(<300 \mathrm{Da})$ and neutral character [41]. These properties can facilitate their application for labeling metabolites (e.g., lipids, sugars) as well as their translation to NIR bioimaging. However, with only a couple of examples being reported to date, the systematic evaluation of the $\mathrm{C}$-bridged nitrobenzodiazole scaffold for 
the development of turn-on molecular probes has not been addressed.

Diversity-oriented fluorescent libraries have been described as a powerful approach for the discovery of new chemosensors [42]. Pioneered by Chang and coworkers, many turn-on fluorescent probes have been identified through the combinatorial derivatisation of fluorophore scaffolds and their systematic screening against biologically-relevant analytes [43-45]. One important advantage of this approach is its versatility, making it compatible with a broad range of chemical structures (including NIR fluorophores) and many different biological analytes. In the present work, we describe a synthetic methodology for the preparation of a small yet diverse collection of C-bridged nitrobenzodiazoles and their systematic spectral characterization against multiple biomolecules, including sugars, lipids, amino acids and metal ions, among others. Through an in vitro fluorescence screening, we identified the benzodiazole 3i as a fluorophore for recognition of $\mathrm{Fe}^{2+}$ ions. Our results demonstrate the potential utility of the C-bridged nitrobenzodiazole scaffold for the preparation of NIR-emitting activatable probes of smaller size than conventional NIR fluorophores.

\section{Experimental}

General materials. Commercially available reagents were used without further purification. Bioanalytes for the screening were obtained from Sigma-Aldrich, TCI and Junsei Chemical. Thin-layer chromatography was conducted on Merck silica gel 60 F254 sheets and visualized by UV (254 and $365 \mathrm{~nm}$ ). Silica gel (particle size 35-70 $\mu \mathrm{m})$ was used for column chromatography. ${ }^{1} \mathrm{H}$ NMR and ${ }^{13} \mathrm{C}$ NMR spectra were recorded in a Bruker Avance
500 spectrometer (at 500 and $125 \mathrm{MHz}$, respectively). Data for ${ }^{1} \mathrm{H}$ NMR spectra are reported as chemical shift $\delta$ (ppm), multiplicity, coupling constant $(\mathrm{Hz})$ and integration. Data for ${ }^{13} \mathrm{C}$ NMR spectra reported as chemical shifts relative to the solvent peak. HPLC-MS analysis was performed on a Waters Alliance 2695 separation module connected to a Waters PDA2996 photodiode array detector and a ZQ Micromass mass spectrometer (ESI-MS) with a Phenomenex $^{\circledR}$ column $\left(\mathrm{C}_{18}, 5 \mu \mathrm{m}, 4.6 \times 150 \mathrm{~mm}\right)$. Highresolution mass spectra (HRMS) were acquired using LTQ Orbitrap Velos with resolving power $>100000$. Highthroughput in vitro screening was performed on a FlexStation3 Multi-Mode Microplate Reader.

Synthesis of 3-fluoro-6-nitrobenzene-1,2-diamine (1). 3-Fluoro-6-nitrobenzoselenadiazole $(2.9 \mathrm{mmol})$ were dissolved in $\mathrm{HCl}$ (concentrated, $30 \mathrm{~mL}$ ) and $\mathrm{HI}(57 \%, 7.5 \mathrm{~mL})$ was added dropwise. The reaction was stirred for $1 \mathrm{~h}$ at r.t. and then a saturated aqueous solution of $\mathrm{Na}_{2} \mathrm{SO}_{3}(100 \mathrm{~mL})$ was added. Afterwards, an aqueous solution of $2 \mathrm{~mol} \cdot \mathrm{L}^{-1}$ $\mathrm{NaOH}$ was added dropwise until the $\mathrm{pH}$ reached 8 . The solution was filtered through Celite and extracted with EtOAc $(4 \times 100 \mathrm{~mL})$. The organic phase was dried over anhydrous $\mathrm{MgSO}_{4}$ and the solvent was removed under reduced pressure to render a dark red solid. Crude product were purified by column chromatography (hexane:EtOAc, $7: 3)$ to give compound $\mathbf{1}$ as an orange solid $(130 \mathrm{mg}, 85 \%$ yield). ${ }^{1} \mathrm{H}$ NMR $\left(500 \mathrm{MHz}\right.$, DMSO- $\left.d_{6}, \delta_{\mathrm{ppm}}\right) 7.40(\mathrm{dd}, J=$ 9.6, $5.8 \mathrm{~Hz}, 1 \mathrm{H}), 7.14(\mathrm{~s}, 2 \mathrm{H}), 6.52(\mathrm{t}, J=9.7 \mathrm{~Hz}, 1 \mathrm{H}), 5.15$ $(\mathrm{s}, 2 \mathrm{H}) .{ }^{13} \mathrm{C}$ NMR $\left(125 \mathrm{MHz}, \mathrm{DMSO}-d_{6}, \delta_{\mathrm{ppm}}\right) 152.6(\mathrm{~d}$, $\left.J_{\mathrm{C}-\mathrm{F}}=242.0 \mathrm{~Hz}\right), 137.8\left(\mathrm{~d}, J_{\mathrm{C}-\mathrm{F}}=9.9 \mathrm{~Hz}\right), 128.6,124.3(\mathrm{~d}$, $\left.J_{\mathrm{C}-\mathrm{F}}=16.1 \mathrm{~Hz}\right), 114.2\left(\mathrm{~d}, J_{\mathrm{C}-\mathrm{F}}=10.1 \mathrm{~Hz}\right), 104.8\left(\mathrm{~d}, J_{\mathrm{C}-\mathrm{F}}=\right.$ $23.2 \mathrm{~Hz})$. HRMS $(m / z, \mathrm{ESI})$ : calcd for $\mathrm{C}_{6} \mathrm{H}_{7} \mathrm{FN}_{3} \mathrm{O}_{2}{ }^{+}[\mathrm{M}+$ $\mathrm{H}]^{+}$: 172.0444 , found: 172.0442 .

General procedure $A$ for the synthesis of 2-fluorobenzazoles (2a-2c). To a solution of compound 1 (1 eq)

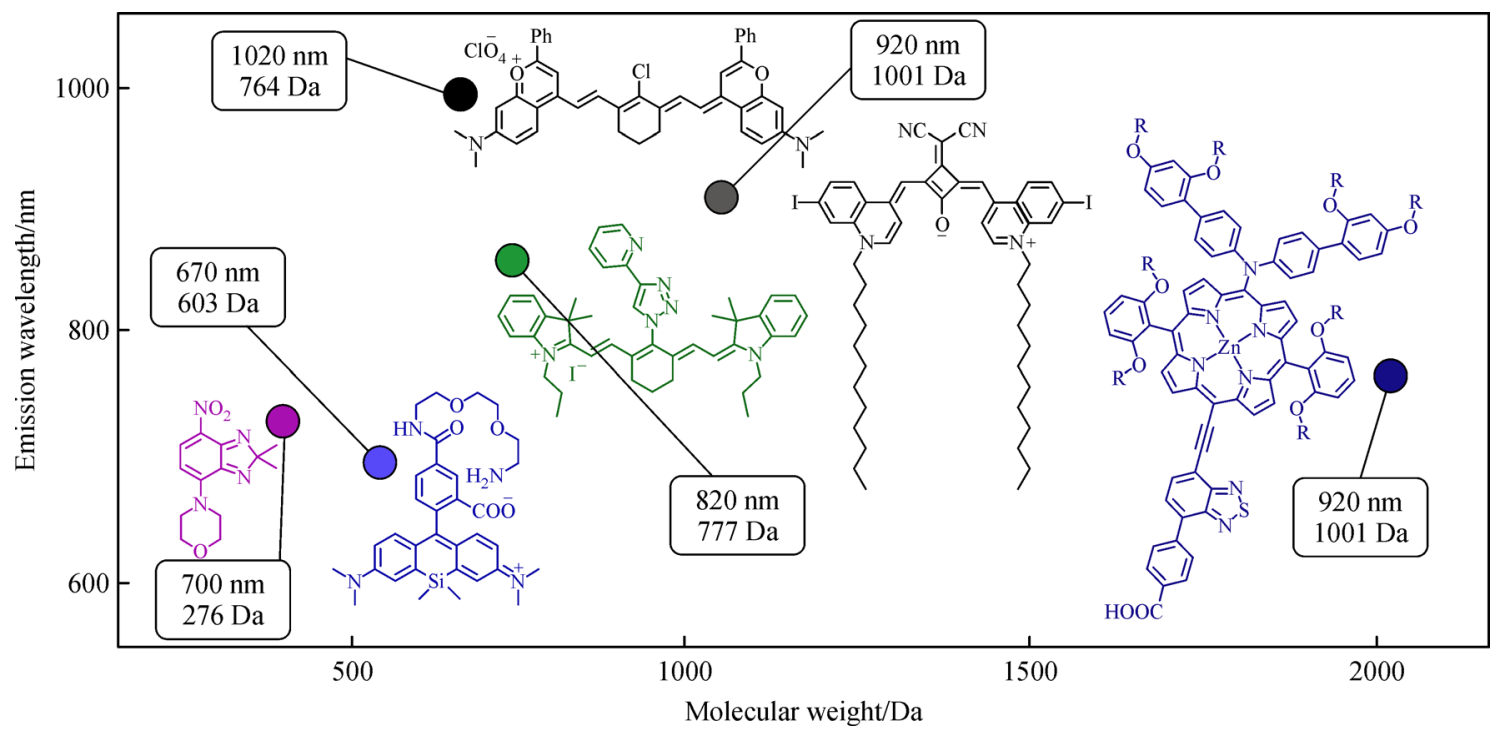

Fig. 1 Structures and featured properties of NIR fluorophores that are representative of different chemical scaffolds. 
in $\mathrm{EtOH}(5 \mathrm{~mL}), \mathrm{Cu}(\mathrm{OAc})_{2}(0.05 \mathrm{eq})$ was added, followed by the corresponding ketone (10 eq). Reaction was heated at $80{ }^{\circ} \mathrm{C}$ overnight. Then, the reaction mixture was filtered through Celite and the solvent was removed under reduced pressure to give the crude products, which were purified by column chromatography. 2a. Red solid $(10 \mathrm{mg}, 80 \%$ yield); eluent: dichloromethane:hexane $=1: 1$. 2b. Red solid (3 mg, 6\% yield); eluent: hexane:EtOAc $=8: 2.2$. Red solid (20 mg, $37 \%$ yield); eluent: dichloromethane: hexane $=7: 3$.

Scale-up synthesis of compound 2a. Following to the general procedure A and $\mathbf{1}(0.3 \mathrm{mmol}, 51 \mathrm{mg}, 1 \mathrm{eq}), \mathrm{EtOH}$ $(5 \mathrm{~mL}), \mathrm{Cu}(\mathrm{OAc})_{2}(0.015 \mathrm{mmol}, 3 \mathrm{mg}, 0.05 \mathrm{eq})$, and acetone (30 mmol, $2.2 \mathrm{~mL}, 10 \mathrm{eq})$ were used. The yield of 2a was $70 \%$ (44 mg). ${ }^{1} \mathrm{H}$ NMR $\left(500 \mathrm{MHz}, \mathrm{CD}_{2} \mathrm{Cl}_{2}, \delta_{\mathrm{ppm}}\right)$ $7.19(\mathrm{dd}, J=9.6,4.6 \mathrm{~Hz}, 1 \mathrm{H}), 6.26(\mathrm{dd}, J=9.3,8.4 \mathrm{~Hz}$, $1 \mathrm{H}), 1.52(\mathrm{~s}, 6 \mathrm{H}) .{ }^{13} \mathrm{C}$ NMR $\left(125 \mathrm{MHz}, \mathrm{CD}_{2} \mathrm{Cl}_{2}, \delta_{\mathrm{ppm}}\right)$ $149.2\left(\mathrm{~d}, J_{\mathrm{C}-\mathrm{F}}=243.8 \mathrm{~Hz}\right), 141.5\left(\mathrm{~d}, J_{\mathrm{C}-\mathrm{F}}=11.2 \mathrm{~Hz}\right), 126.7$ $\left(\mathrm{d}, J_{\mathrm{C}-\mathrm{F}}=17.1 \mathrm{~Hz}\right), 114.9\left(\mathrm{~d}, J_{\mathrm{C}-\mathrm{F}}=8.5 \mathrm{~Hz}\right), 107.1\left(\mathrm{~d}, J_{\mathrm{C}-\mathrm{F}}\right.$ $=22.2 \mathrm{~Hz}), 81.9,30.2$. HRMS $(\mathrm{m} / \mathrm{z}$, ESI): calcd for $\mathrm{C}_{9} \mathrm{H}_{9} \mathrm{FN}_{3} \mathrm{O}_{2}[\mathrm{M}+\mathrm{H}]^{+}: 210.0673$, found: 210.0673 .

General procedure $B$ for the synthesis of 2-aminobenzazoles $(3 \mathbf{a}-\mathbf{3 k})$. To solutions of compounds $\mathbf{2 a}-\mathbf{2} \mathbf{c}(1$ eq) in $\mathrm{MeCN}(1 \mathrm{~mL}), \mathrm{NaHCO}_{3}(2.5 \mathrm{eq})$ in $\mathrm{H}_{2} \mathrm{O}(1 \mathrm{~mL})$ was added, followed by amines (1 eq) and the reactions were heated at $65{ }^{\circ} \mathrm{C}$ or stirred at r.t. until completion. The reaction mixtures were diluted with EtOAc and washed with $0.2 \mathrm{~mol} \cdot \mathrm{L}^{-1} \mathrm{HCl}$ and brine. Organic layers were dried over anhydrous $\mathrm{MgSO}_{4}$, concentrated under reduced pressure and purified by column chromatography or preparative TLC. 3a. Purple solid ( $2 \mathrm{mg}, 80 \%$ yield); eluent: dichloromethane:MeOH = 95:5. 3b. Purple solid (1 $\mathrm{mg}, 6 \%$ yield); eluent: dichloromethane:EtOAc $=9: 1.3 \mathrm{c}$. Purple solid (1 mg, 9\% yield); eluent: hexane:EtOAc $=4: 6$. 3d. Purple solid (2 mg, $23 \%$ yield); eluent: dichloromethane: $\mathrm{MeOH}=95: 5$. 3e. Purple solid $(2 \mathrm{mg}, 40 \%$ yield); eluent: dichloromethane: $\mathrm{MeOH}=$ 95:5. 3f. Purple solid (5 mg, 41\% yield); eluent: dichloromethane: $\mathrm{MeOH}=$ 95:5. 3g. Purple solid (3 mg, 34\% yield); eluent: dichloromethane: $\mathrm{MeOH}=95: 5$. 3h. Purple solid (1 mg, 4\% yield); eluent: dichloromethane: $\mathrm{MeOH}=$ 95:5. 3i. Purple solid (1 mg, 15\% yield); eluent: dichloromethane: $\mathrm{MeOH}=$ 95:5. 3j. Purple solid (2 $\mathrm{mg}, 24 \%$ yield); dichloromethane: $\mathrm{MeOH}=95: 5$. 3k. Brown solid $(1 \mathrm{mg}$, $7 \%$ yield); eluent: dichloromethane: $\mathrm{MeOH}=95: 5$.

Scale-up synthesis of hit compound 3i. Following to the general procedure $B$ and $\mathbf{2 a}(0.09 \mathrm{mmol}, 19 \mathrm{mg}, 1 \mathrm{eq})$, $\mathrm{MeCN}(1 \mathrm{~mL}), \mathrm{NaHCO}_{3}(0.23 \mathrm{mmol}, 20 \mathrm{mg}, 2.5 \mathrm{eq}), \mathrm{H}_{2} \mathrm{O}$ $(1 \mathrm{~mL})$, morpholine $(0.23 \mathrm{mmol}, 18 \mu \mathrm{L}, 2.5 \mathrm{eq})$ were used. The yield of $3 \mathbf{i}$ was $13 \%(3 \mathrm{mg}) .{ }^{1} \mathrm{H}$ NMR $(500 \mathrm{MHz}$, $\left.\mathrm{CD}_{2} \mathrm{Cl}_{2}, \delta_{\mathrm{ppm}}\right) 8.22(\mathrm{~d}, J=8.9 \mathrm{~Hz}, 1 \mathrm{H}), 5.78(\mathrm{~d}, J=8.9 \mathrm{~Hz}$, $1 \mathrm{H}), 4.07-3.97(\mathrm{~m}, 4 \mathrm{H}), 3.78-3.74(\mathrm{~m}, 4 \mathrm{H}), 1.50(\mathrm{~s}, 6 \mathrm{H})$. ${ }^{13} \mathrm{C}$ NMR $\left(125 \mathrm{MHz}, \mathrm{CD}_{2} \mathrm{Cl}_{2}, \delta_{\mathrm{ppm}}\right) 154.7,151.5,149.6$, 140.3, 115.3, 105.2, 100.3, 65.7, 48.4, 21.1. HRMS $(\mathrm{m} / \mathrm{z}$, ESI): calcd for $\mathrm{C}_{13} \mathrm{H}_{17} \mathrm{~N}_{4} \mathrm{O}_{3}[\mathrm{M}+\mathrm{H}]^{+}: 277.1295$, found: 277.1301 .

\section{Results and discussion}

3.1 Chemical synthesis of a library of C-bridged nitrobenzodiazoles

Building on the recently reported SCOTfluors [41], which feature a benzodiazole core as a fluorogenic scaffold, we designed the synthesis of a small collection of C-bridged benzodiazoles using a two-step protocol with a readily accessible common precursor (compound 1, Fig. 2) and commercially available ketone and amine building blocks. We obtained 2-fluoro-4-nitro-o-phenylenediamine $\mathbf{1}$ in good yields and then utilized it in Cu-catalyzed condensations with ketones to render the intermediate C-bridged benzodiazoles (2, Fig. 2). Subsequently, we performed nucleophilic aromatic substitutions to conjugate an array of primary and secondary amines and render the final NIRemitting products (3, Fig. 2). First, we employed acetone as the main carbonyl input to enable the formation of the smallest C-bridged benzodiazoles with methyl groups as substituents. In parallel, we also assessed Cu-catalyzed condensations with two aromatic ketones (i.e., acetophenone and 4-nitroacetophenone) to explore the scope of the reaction and analyze the effect of different substituents on the spectral properties of C-bridged benzodiazoles. While the condensation of the starting material $\mathbf{1}$ with acetone proceeded smoothly to afford compound $\mathbf{2 a}$ in $79 \%$ yield, acetophenones showed very poor reactivity, likely due to steric hindrance and electron-donating effects. As a result, compounds $\mathbf{2 b}$ and $\mathbf{2 c}$ were isolated only in poor yields (6\% and $37 \%$, respectively), even after prolonged heating for multiple days. Attempts at improving these yields by addition of fresh catalyst or additional equivalents of ketone did not improve the poor conversion rates.

Next, the conjugation reactions with a chemicallydiverse set of amine building blocks were run in water/ acetonitrile in the presence of sodium bicarbonate as a base. These conditions ensured full solubility of the reagents and activation of the nucleophilic amine group. Initially, $N, N^{\prime}$-diethylamine was employed to assess the reactivity of different benzodiazole intermediates (e.g., compounds 2a-2c). While 2a underwent a clean conversion into the corresponding 3a with yields over $80 \%$, derivatives bearing aromatic substituents turned out to be problematic with yields for compounds $\mathbf{3 b}$ and $\mathbf{3 c}$ below $10 \%$. We therefore choose to employ the compound $2 \mathbf{a}$ for further derivatisation and preparation of the C-bridged benzodiazole library. Simple primary amines (e.g., $\mathrm{N}$ propylamine, aminohexanoic acid) were found to react well, and both compounds $\mathbf{3 d}$ and $\mathbf{3 e}$ were isolated in moderate yields between $20 \%$ and $40 \%$. On the other hand, secondary amines other than $N, N^{\prime}$-diethylamine gave mixed results. Piperidine and $N$-methylallylamine derivatives $\mathbf{3 f}$ and $\mathbf{3 g}$ were also obtained in comparable yields, but the use of $\mathrm{N}$-ethylcyclohexylamine rendered compound $\mathbf{3 h}$ in trace amounts. Finally, we also attempted the 
formation of morpholine and benzylamine derivatives. Of note, during these reactions we observed the formation of double substitution products. For the morpholino derivative we could isolate both mono and disubstituted benzodiazoles (3i and $\mathbf{3 j}$, respectively) whereas the benzylamine derivative was only isolated as the disubstituted analog (3k).

3.2 In vitro screening of C-bridged nitrobenzodiazoles with biological analytes

After the synthesis of a collection of C-bridged benzodiazoles, we analyzed their spectral properties. Most compounds exhibited absorbance maxima wavelengths around $570 \mathrm{~nm}$ and broad fluorescence emission in the 650
$750 \mathrm{~nm}$ range. Comparative analysis within the library highlighted some differences between the differently substituted compounds $\mathbf{3 a}, \mathbf{3 b}$ and $\mathbf{3 c}$. Of note, compounds $\mathbf{3 b}$ and 3c, which incorporate an aromatic residue at the bridging position, displayed around $20 \mathrm{~nm}$ longer emission maxima wavelengths than compound 3a. On the other hand, the incorporation of different amines at the position 4 of the C-bridged benzodiazoles did not lead to major changes in their emission wavelengths (Table S1, cf. Electronic Supplementary Material, ESM).

Little is known about the potential of the C-bridged benzodiazole scaffold for the development of fluorescent biomolecules, so we decided to systematically investigate the fluorescence responses of all benzodiazoles against a broad range of biological analytes under physiological

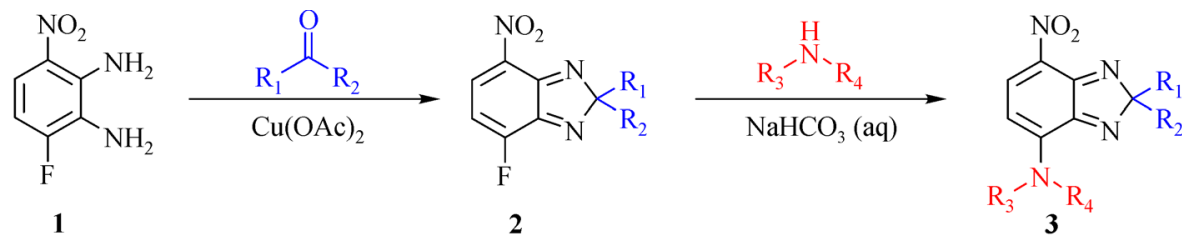

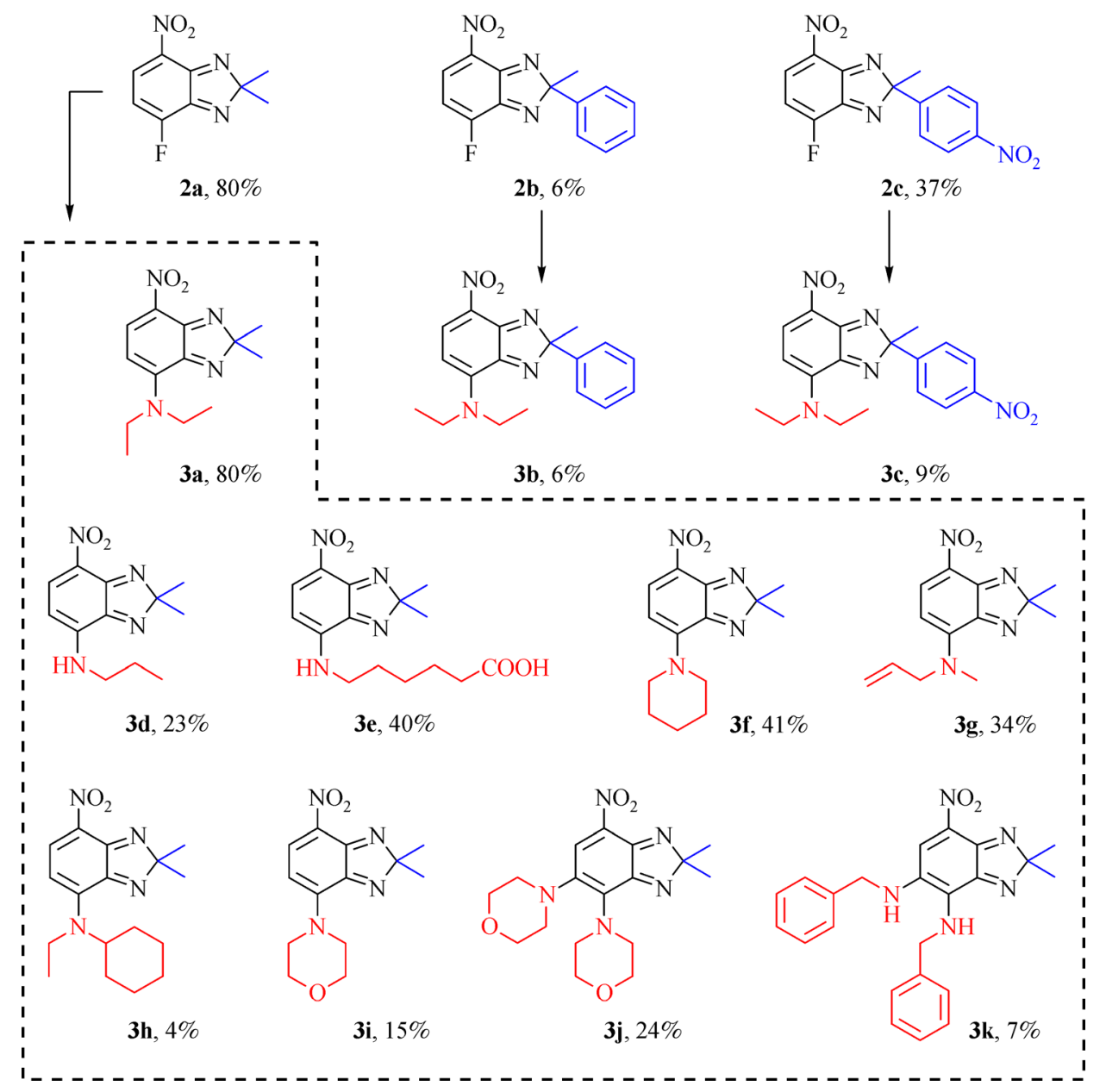

Fig. 2 Synthetic strategy for the preparation of NIR-emitting C-bridged benzodiazoles and chemical structures of the isolated compounds with their respective synthetic yields. 
conditions. Diversity-oriented fluorescence libraries have been proven an effective approach for the identification of environmentally-sensitive fluorophores as well as analyteresponding probes [42]. First, we run a fluorescence response profiling analysis by monitoring the fluorescent intensity changes of $11 \mathrm{C}$-bridged benzodiazoles against 60 biometabolites including amino acids (asparagine, isoleucine, tyrosine, lysine, tryptophan, alanine, arginine, asparagine, phenylalanine, methionine, proline, valine, glutamine, histidine, leucine, glutamate, serine, glycine and threonine), oxidant and reducing agents (cysteine, homocysteine, glutathione, glutathione disulfide (GSSG), $\mathrm{H}_{2} \mathrm{O}_{2}, \mathrm{OCl}^{-}, \cdot \mathrm{OH},{ }^{1} \mathrm{O}_{2}, \mathrm{NO}, \mathrm{NaSH}$ and $\cdot \mathrm{O}_{2}$ ), sugars (arabinose, glucose, fructose, galactose, sucrose, maltose, mannose and glycogen), steroids (estriol, chloric acid, dexamethasone, estrone, $\beta$-estradiol, 4-androsterene-3,17dione), metal ions $\left(\mathrm{Fe}^{3+}, \mathrm{Fe}^{2+}, \mathrm{Cu}^{2+}, \mathrm{Cu}^{+}, \mathrm{Ca}^{2+}, \mathrm{Mg}^{2+}\right.$, $\mathrm{Zn}^{+}, \mathrm{Hg}^{2+}, \mathrm{Sn}^{2+}$ and $\mathrm{Pd}^{2+}$ ), nucleic acids (DNA) and proteins (bovine serum albumin, human serum albumin, lysozyme and peroxidase). To maximise the reliability of our primary screening, we configured the assay conditions with four serial concentrations for each analyte in these ranges: $0.1-100 \mu \mathrm{mol} \cdot \mathrm{L}^{-1}$ for steroids, $2-2000 \mu \mathrm{g} \cdot \mathrm{mL}^{-1}$ for proteins, $0.31-310 \mathrm{pg} \cdot \mu \mathrm{L}^{-1}$ for DNA and $1-1000 \mu \mathrm{mol}$ $\cdot \mathrm{L}^{-1}$ for all other analytes.

A total of 2640 combinations (11 C-bridged benzodiazoles $\times 60$ analytes $\times 4$ concentrations) were examined. To simplify the visualization and analysis of the generated data, we calculated the fluorescence intensities for each compound as emission fold changes in the absence and in the presence of the different analytes and plotted them as a pseudo-colored heat map (Fig. 3). The overall average fold change observed for our library of compounds was determined as of 1.098, which indicates that the majority of benzodiazoles remained fluorescently silent and did not show bright emission and highlight their potential as fluorogenic probes. However, some of the screened compounds displayed moderate to good fluorescence increases upon incubation with specific analytes and we could identify several probe/analyte pairs with turn-on responses (for a detailed summary of the screening results, see Table S2 (cf. ESM)). Interestingly, compounds $\mathbf{3 i}$ and $\mathbf{3 j}$, which both contain morpholine groups, were found to be a notable exception and displayed some remarkable reactivity against metal cations. Compound $\mathbf{3 j}$ showed bright fluorescence emission upon incubation with different metal ions $\left(\mathrm{Fe}^{2+}, \mathrm{Cu}^{2+}, \mathrm{Cu}^{+}, \mathrm{Hg}^{2+}\right.$ and $\left.\mathrm{Pd}^{2+}\right)$ but also displayed high reactivity with other analytes (GSSG, $\mathrm{H}_{2} \mathrm{O}_{2}, \cdot \mathrm{OH}, \mathrm{NO}, \mathrm{NaSH}$ and Leu, among others). On the other hand, compound $\mathbf{3 i}$ showed a significant fluorescence emission increase upon 10 min incubation with $\mathrm{Fe}^{2+}$ ions in aqueous solution and good selectivity over other metal cations and biologically-relevant molecules (Fig. 3). In the view of these results, and due to the biological relevance of iron species and to the ability of this fluorophore to discriminate between very similar analytes (i.e., $\mathrm{Fe}^{2+}$ and $\mathrm{Fe}^{3+}$ ions), we scaled up the synthesis of compound $\mathbf{3 i}$ for further analytical characterization.

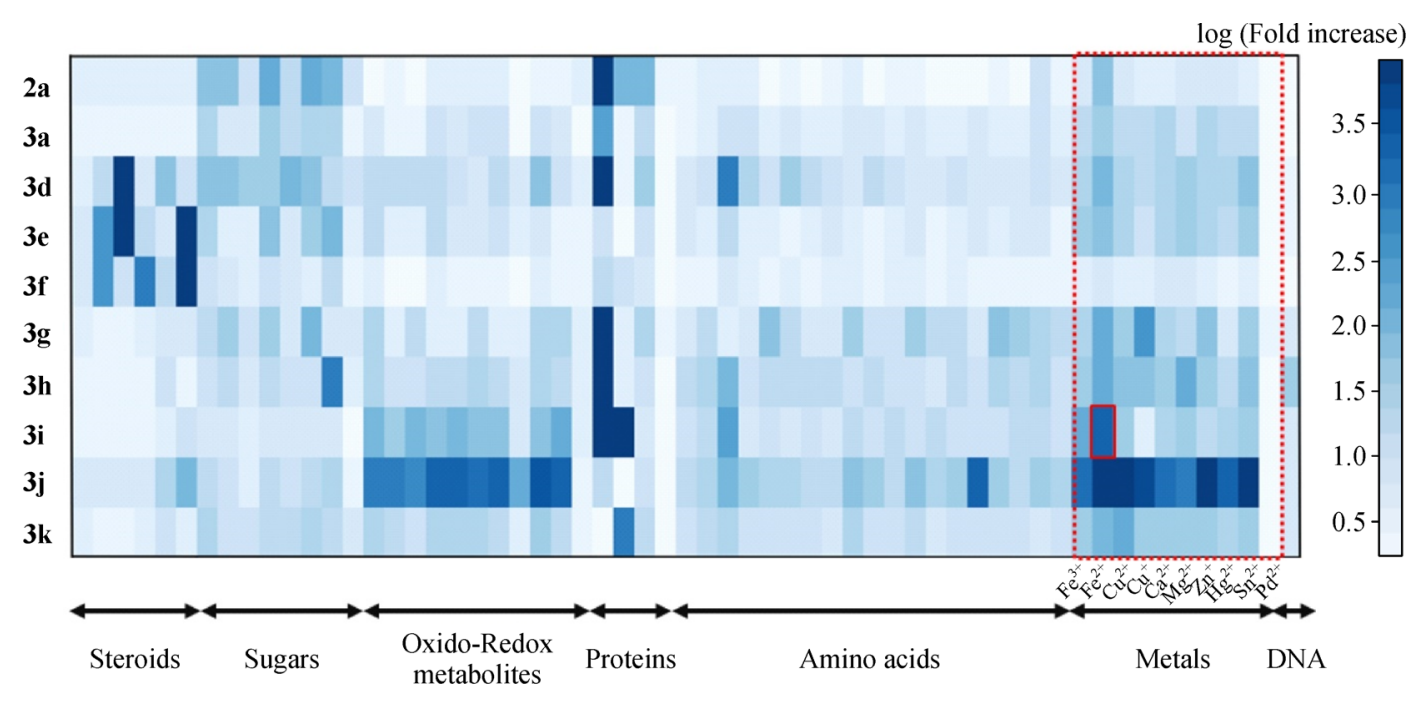

Fig. 3 Representative heatmap with the fluorescence intensity of C-bridged benzodiazoles (2a-3k) at the highest concentration of analyte, including steroids (estriol, chloric acid, dexamethasone, estrone, $\beta$-estradiol, 4-androsterene-3,17-dione) with $2 \%$ EtOH in phosphate buffered saline (PBS) pH 7.4; sugars (arabinose, glucose, fructose, galactose, sucrose, maltose, mannose and glycogen); redoxrelated molecules (cysteine, homocysteine, glutathione, GSSG, $\mathrm{H}_{2} \mathrm{O}_{2}, \mathrm{OCl}^{-}, \cdot \mathrm{OH},{ }^{1} \mathrm{O}_{2}, \mathrm{NO}, \mathrm{NaSH}$ and $\bullet \mathrm{O}_{2}$ ); proteins (bovine serum albumin, human serum albumin, lysozyme and peroxidase); amino acids (asparagine, isoleucine, tyrosine, lysine, tryptophan, alanine, arginine, asparagine, phenylalanine, methionine, proline, valine, glutamine, histidine, leucine, glutamate, serine, glycine and threonine); metal ions $\left(\mathrm{Fe}^{3+}, \mathrm{Fe}^{2+}, \mathrm{Cu}^{2+}, \mathrm{Cu}^{+}, \mathrm{Ca}^{2+}, \mathrm{Mg}^{2+}, \mathrm{Zn}^{+}, \mathrm{Hg}^{2+}, \mathrm{Sn}^{2+}\right.$ and $\mathrm{Pd}^{2+}$ ) and DNA (all of those in PBS pH 7.4). The response of compound $\mathbf{3 i}$ to metal ions is highlighted in red. 


\subsection{Compound $\mathbf{3 i}$ shows a differential fluorescence} response to $\mathrm{Fe}^{2+}$ and $\mathrm{Fe}^{3+}$ ions in aqueous media

Iron is an abundant and essential transition metal involved in several physiologic processes such as oxygen delivery, electron transport and enzymatic reactions [46]. Disruption of iron homeostasis leads to oxidative stress and cellular damage, which in turn play a significant role in the onset of cardiovascular diseases, neurodegenerative disorders and cancer [47]. Specifically, lysosomes require $\mathrm{Fe}^{2+}$ ions to catalyze Fenton-type reactions with hydrogen peroxide to generate reactive oxygen species and contain such species in high micromolar concentrations [48,49].

To assess the potential of compound $3 \mathbf{i}$ for the fluorescence detection of $\mathrm{Fe}^{2+}$ ions, we first recorded the fluorescence spectra of compound $\mathbf{3 i}$ in aqueous solutions containing different concentrations of the metal cation (Fig. 4). Because C-bridged benzodiazoles display low fluorescence quantum yields, concentrations of compound $3 \mathbf{i}$ in the high micromolar range $\left(100-200 \mu \mathrm{mol} \cdot \mathrm{L}^{-1}\right)$ were needed to record proper emission spectra. As observed in the primary screening, a slight fluorescence increase was detected in the presence of $\mathrm{Fe}^{2+}$ ions (Fig. 4(a), quantum yield increased from $2.5 \%$ to $4.7 \%$ ). Next, we analyzed whether compound $\mathbf{3 i}$ would respond differently to other iron species and observed a clear difference between the fluorescence and colorimetric response to $\mathrm{Fe}^{2+}$ and $\mathrm{Fe}^{3+}$ solutions at the same concentration, always using chloride as the counteranion. Compound $\mathbf{3 i}$ showed extinction coefficients around $7800 \mathrm{~L} \cdot \mathrm{mol}^{-1} \cdot \mathrm{cm}^{-1}$ at $560 \mathrm{~nm}$ (Fig. S2, cf. ESM) and a clear colorimetric shift from purple to blue from $\mathrm{Fe}^{2+}$ to $\mathrm{Fe}^{3+}$ together with a drastic reduction of its fluorescence emission (Fig. 4(b)). Notably, we replicated this response when we incubated compound 3i with solutions of $\mathrm{Fe}^{2+}$ that had been treated with ethylenediaminetetraacetic acid (EDTA), which suggests that the behavior of compound $\mathbf{3 i}$ might be related to the chelation of $\mathrm{Fe}^{2+}$ ions. We also performed a Job plot analysis to study the complex formed between compound $\mathbf{3 i}$ and $\mathrm{Fe}^{2+}$ and observed a maximal response for a 1:1 stoichiometry (Fig. S3, cf. ESM). Furthermore, to analyze whether compound $3 \mathbf{i}$ would show a differential aggregation profile in aqueous solutions that contained $\mathrm{Fe}^{2+}$ or $\mathrm{Fe}^{3+}$ ions, we performed dynamic light scattering experiments. In these assays, we observed the formation of large aggregates when compound $\mathbf{3 i}$ was incubated with aqueous $\mathrm{FeCl}_{2}$ but no changes in aggregation for $\mathrm{FeCl}_{3}$ solutions (Fig. 4(c)).

Altogether, our results indicate compound $\mathbf{3 i}$ as a fluorogenic molecule for the detection of $\mathrm{Fe}^{2+}$ in aqueous media with a clear differential response to other metal cations, particularly to $\mathrm{Fe}^{3+}$ ions. Future studies with compound $\mathbf{3 i}$ will involve its evaluation as a probe for imaging the trafficking of intracellular $\mathrm{Fe}^{2+}$ in live cells.

\section{Conclusions}

In summary, herein we report the synthesis of the first small collection of C-bridged benzodiazoles and their systematic characterization as potential fluorogenic molecules with NIR emission. Through a diversity-oriented fluorescence screening using 60 chemically-diverse biomolecules, we observed that $\mathrm{C}$-bridged benzodiazoles are inherently silent molecules and with potential to turn on their fluorescence response upon incubation with different analytes. From our screening we observed that morpholino-containing benzodiazoles showed remarkable response against metal cations and we further studied the behavior of compound $\mathbf{3 i}$ for the detection of $\mathrm{Fe}^{2+}$ ions. Compound 3i showed increased fluorescence emission in the presence of equal amounts of $\mathrm{Fe}^{2+}$ ions, whereas the signals were drastically reduced in the presence of $\mathrm{Fe}^{3+}$
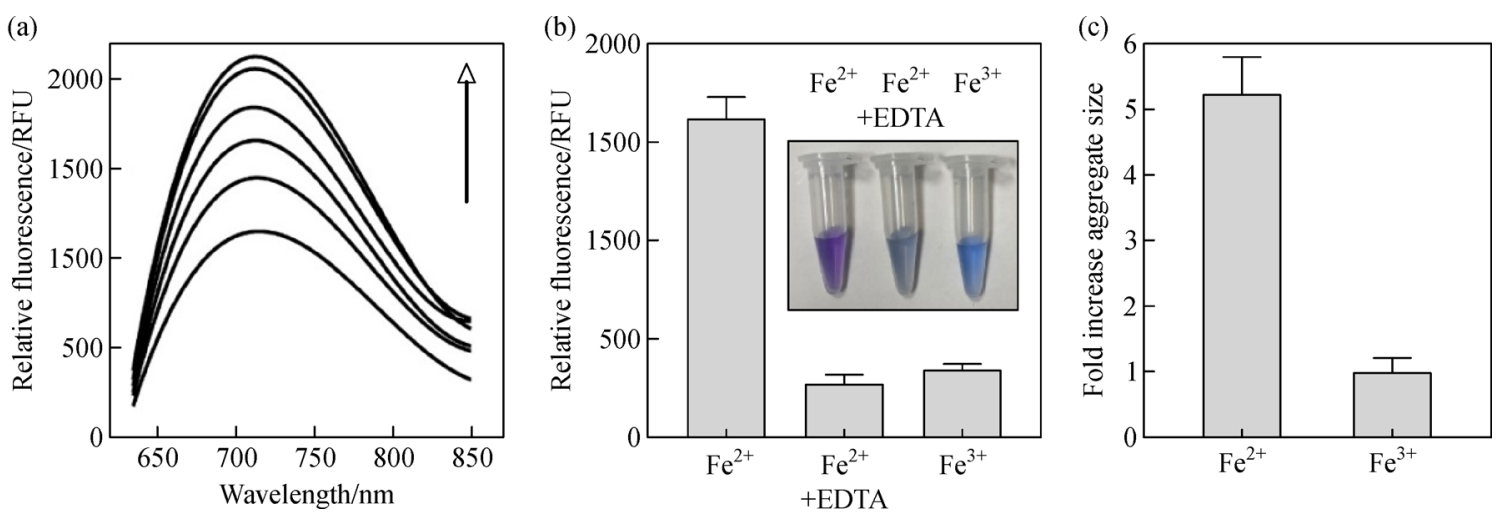

Fig. 4 (a) Fluorescence spectra of compound $3 \mathbf{i}\left(200 \mu \mathrm{mol} \cdot \mathrm{L}^{-1}\right)$ after incubation with increasing concentrations of aqueous $\mathrm{FeCl}_{2}$ $\left(0,0.125,0.25,0.5,1\right.$ and $\left.2 \mathrm{mmol} \cdot \mathrm{L}^{-1}\right), \lambda_{\text {exc }}: 570 \mathrm{~nm}$; (b) fluorescence intensity of compound $3 \mathbf{i}\left(200 \mu \mathrm{mol} \cdot \mathrm{L}^{-1}\right)$ after incubation with different iron species $\left(\mathrm{FeCl}_{2}\right.$ and $\mathrm{FeCl}_{3}: 1 \mathrm{mmol} \cdot \mathrm{L}^{-1}$; EDTA: $\left.1 \mathrm{mmol} \cdot \mathrm{L}^{-1}\right)$, inset: pictograms of the different solutions under white light; (c) dynamic light scattering measurement of aggregates formed after 60 -min incubation of compound $3 \mathbf{i}\left(200 \mu \mathrm{mol} \cdot \mathrm{L}^{-1}\right) \mathrm{with} 2 \mathrm{mmol} \cdot \mathrm{L}^{-1}$ $\mathrm{FeCl}_{2}$ or $2 \mathrm{mmol} \cdot \mathrm{L}^{-1} \mathrm{FeCl}_{3}$. Plots show the relative increase aggregate size when compared to an aqueous solution of compound $3 \mathbf{i}$ $\left(200 \mu \mathrm{mol} \cdot \mathrm{L}^{-1}\right)$. Data presented as means $\pm \mathrm{SD}(n=3-6)$. 
ions. Mechanistic assays suggest that the response of compound 3i might be related to chelation - as seen in experiments with EDTA or aggregation-followed by light scattering experiments. The expansion of the C-bridged benzodiazole toolbox with additional commercially-available amine and/or ketone building blocks will accelerate the development of NIR chemosensors with multiple applications in analytical and biological chemistry.

Acknowledgements The authors acknowledge funding from Medical Research Scotland (Sam Benson: 879-2015) and an ERC Consolidator Grant (DYNAFLUORS, Marc Vendrell: 771443). This work was also supported by National Research Foundation funded by the Ministry of Science, ICT \& Future Planning, South Korea (Jun-Seok Lee: NRF2018M3A9H4079286, NRF-2020R1A2C2004422).

Electronic Supplementary Material Supplementary material is available in the online version of this article at https://dx.doi.org/10.1007/s11705-021$2080-8$ and is accessible for authorized users.

Open Access This article is licensed under a Creative Commons Attribution 4.0 International License, which permits use, sharing, adaptation, distribution and reproduction in any medium or format, as long as you give appropriate credit to the original author(s) and the source, provide a link to the Creative Commons licence, and indicate if changes were made. The images or other third party material in this article are included in the article's Creative Commons licence, unless indicated otherwise in a credit line to the material. If material is not included in the article's Creative Commons licence and your intended use is not permitted by statutory regulation or exceeds the permitted use, you will need to obtain permission directly from the copyright holder. To view a copy of this licence, visit http://creativecommons.org/licenses/by/4.0/.

\section{References}

1. Park S J, Yeo H C, Kang N Y, Kim H, Lin J, Ha H H, Vendrell M, Lee J S, Chandran Y, Lee D Y, et al. Mechanistic elements and critical factors of cellular reprogramming revealed by stepwise global gene expression analyses. Stem Cell Research (Amsterdam), 2014, 12(3): 730-741

2. Carter K P, Young A M, Palmer A E. Fluorescent sensors for measuring metal ions in living systems. Chemical Reviews, 2014, 114(8): 4564-4601

3. Jiao X Y, Li Y, Niu J Y, Xie X L, Wang X, Tang B. Small-molecule fluorescent probes for imaging and detection of reactive oxygen, nitrogen, and sulfur species in biological systems. Analitycal Chemistry, 2018, 90(1): 533-555

4. Han J Y, Burgess K. Fluorescent indicators for intracellular $\mathrm{pH}$. Chemical Reviews, 2010, 110(5): 2709-2728

5. Dedecker P, De Schryver F C, Hofkens J. Fluorescent proteins: shine on, you crazy diamond. Journal of the American Chemical Society, 2013, 135(7): 2387-2402

6. Gong J, Liu C, Jiao X J, He S, Zhao L C, Zeng X S. A novel nearinfrared fluorescent probe with an improved Stokes shift for specific detection of $\mathrm{Hg}^{2+}$ in mitochondria. Organic \& Biomolecular Chemistry, 2020, 18(27): 5238-5244

7. Kwon H Y, Liu X, Choi E G, Lee J Y, Choi S Y, Kim J Y, Wang L, Park S J, Kim B, Lee Y A, et al. Development of a universal fluorescent probe for gram-positive bacteria. Angewandte Chemie
International Edition, 2019, 58(25): 8426-8431

8. Devaraj N K, Weissleder R. Biomedical applications of tetrazine cycloadditions. Accounts of Chemical Research, 2011, 44(9): 816827

9. Chen G Q, Guo Z, Zeng G M, Tang L. Fluorescent and colorimetric sensors for environmental mercury detection. Analyst (London), 2015, 140(16): 5400-5443

10. Chan J, Dodani S C, Chang C J. Reaction-based small-molecule fluorescent probes for chemoselective bioimaging. Nature Chemistry, 2012, 4(12): 973-984

11. Duong T Q, Kim J S. Fluoro- and chromogenic chemodosimeters for heavy metal ion detection in solution and biospecimens. Chemical Reviews, 2010, 110(10): 6280-6301

12. Yraola F, Ventura R, Vendrell M, Colombo A, Fernandez J C, de la Figuera N, Fernandez-Forner D, Royo M, Forns P, Albericio F. A re-evaluation of the use of rink, BAL, and PAL resins and linkers. QSAR \& Combinatorial Science, 2004, 23(2-3): 145-152

13. Sainlos M, Iskenderian W S, Imperiali B. A general screening strategy for peptide-based fluorogenic ligands: probes for dynamic studies of PDZ domain-mediated interactions. Journal of the American Chemical Society, 2009, 131(19): 6680-6682

14. Kalstrup T, Blunck R. Dynamics of internal pore opening in K(V) channels probed by a fluorescent unnatural amino acid. Proceedings of the National Academy of Sciences of the United States of America, 2013, 110(20): 8272-8277

15. Sachdeva A, Wang K H, Elliott T, Chin J W. Concerted, rapid, quantitative, and site-specific dual labeling of proteins. Journal of the American Chemical Society, 2014, 136(22): 7785-7788

16. Lampkowski J S, Uthappa D M, Young D D. Site-specific incorporation of a fluorescent terphenyl unnatural amino acid. Bioorganic \& Medicinal Chemistry Letters, 2015, 25(22): 52775280

17. FitzGerald L I, Aurelio L, Chen M, Yuen D, Rennick J J, Graham B, Johnston A P R. A molecular sensor to quantify the localization of proteins, DNA and nanoparticles in cells. Nature Communications, 2020, 11(1): 1-13

18. Fernandez A, Vermeren M, Humphries D, Subiros-Funosas R, Barth N, Campana L, MacKinnon A, Feng Y, Vendrell M. Chemical modulation of in vivo macrophage function with subpopulationspecific fluorescent prodrug conjugates. ACS Central Science, 2017, 3(9): 995-1005

19. Subiros-Funosas R, Mendive-Tapia L, Sot J, Pound J D, Barth N, Varela Y, Goni F M, Paterson M, Gregory C D, Albericio F, et al. A Trp-BODIPY cyclic peptide for fluorescence labelling of apoptotic bodies. Chemical Communications, 2017, 53(5): 945-948

20. Barth N D, Subiros-Funosas R, Mendive-Tapia L, Duffin R, Shields M A, Cartwright J A, Henriques S T, Sot J, Goni F M, Lavilla R, et al. A fluorogenic cyclic peptide for imaging and quantification of drug-induced apoptosis. Nature Communications, 2020, 11(1): $1-14$

21. Osseiran S, Austin L A, Cannon T M, Yan C, Langenau D M, Evans C L. Longitudinal monitoring of cancer cell subpopulations in monolayers, 3D spheroids, and xenografts using the photoconvertible dye DiR. Scientific Reports, 2019, 9(1): 1-10

22. Anorma C, Hedhli J, Bearrood T E, Pino N W, Gardner S H, Inaba H, Zhang P, Li Y F, Feng D, Dibrell S E, et al. Surveillance of cancer 
stem cell plasticity using an isoform-selective fluorescent probe for aldehyde dehydrogenase 1A1. ACS Central Science, 2018, 4(8): 1045-1055

23. Barth N D, Marwick J A, Vendrell M, Rossi A G, Dransfield I. The "Phagocytic synapse" and clearance of apoptotic cells. Frontiers in Immunology, 2017, 8: 1708-1717

24. Yi Z, Luo Z, Barth N D, Meng X, Liu H, Bu W, All A, Vendrell M, Liu X. In vivo tumor visualization through MRI off-on switching of $\mathrm{NaGdF} 4-\mathrm{CaCO}_{3}$ nanoconjugates. Advanced Materials, 2019, 31(37): e1901851

25. Samanta A, Vendrell M, Yun S W, Guan Z, Xu Q H, Chang Y T. A photostable near-infrared protein labeling dye for in vivo imaging. Chemistry, an Asian Journal, 2011, 6(6): 1353-1357

26. Chen C, Tian R, Zeng Y, Chu C C, Liu G. Activatable fluorescence probes for "turn-on" and ratiometric biosensing and bioimaging: from NIR-I to NIR-II. Bioconjugate Chemistry, 2020, 31(2): 276292

27. Wang P Y, Fan Y, Lu L F, Liu L, Fan L L, Zhao M Y, Xie Y, Xu C J, Zhang F. NIR-II nanoprobes in-vivo assembly to improve imageguided surgery for metastatic ovarian cancer. Nature Communications, 2018, 9(1): 1-10

28. Vahrmeijer A L, Hutteman M, van der Vorst J R, van de Velde C J H, Frangioni J V. Image-guided cancer surgery using near-infrared fluorescence. Nature Reviews. Clinical Oncology, 2013, 10(9): 507518

29. Guo Z Q, Park S, Yoon J, Shin I. Recent progress in the development of near-infrared fluorescent probes for bioimaging applications. Chemical Society Reviews, 2014, 43(1): 16-29

30. Wirth R, Gao P, Nienhaus G U, Sunbul M, Jaschke A. SiRA: a silicon rhodamine-binding aptamer for live-cell super-resolution RNA imaging. Journal of the American Chemical Society, 2019, 141(18): 7562-7571

31. Koide Y, Urano Y, Hanaoka K, Piao W, Kusakabe M, Saito N, Terai T, Okabe T, Nagano T. Development of NIR fluorescent dyes based on Si-rhodamine for in vivo imaging. Journal of the American Chemical Society, 2012, 134(11): 5029-5031

32. Ramos A A, Nascimento F B, de Souza T F M, Omori A T, Manieri T M, Cerchiaro G, Ribeiro A O. Photochemical and photophysical properties of phthalocyanines modified with optically active alcohols. Molecules (Basel, Switzerland), 2015, 20(8): 1357513590

33. Pal A K, Varghese S, Cordes D B, Slawin A M Z, Samuel I D W, Zysman-Colman E. Near-infrared fluorescence of silicon phthalocyanine carboxylate esters. Scientific Reports, 2017, 7(1): 1-14

34. Wong R C H, Lo P C, Ng D K P. Stimuli responsive phthalocyaninebased fluorescent probes and photosensitizers. Coordination Chemistry Reviews, 2019, 379: 30-46

35. Ilina K, MacCuaig W M, Laramie M, Jeouty J N, McNally L R, Henary M. Squaraine dyes: molecular design for different applications and remaining challenges. Bioconjugate Chemistry, 2020, 31(2): 194-213
36. Xia G M, Wang H M. Squaraine dyes: the hierarchical synthesis and its application in optical detection. Journal of Photochemistry and Photobiology A Chemistry, 2017, 31: 84-113

37. Mathew S, Yella A, Gao P, Humphry-Baker R, Curchod B F E, Ashari-Astani N, Tavernelli I, Rothlisberger U, Nazeeruddin M K, Gratzel M. Dye-sensitized solar cells with $13 \%$ efficiency achieved through the molecular engineering of porphyrin sensitizers. Nature Chemistry, 2014, 6(3): 242-247

38. Mellanby R J, Scott J I, Mair I, Fernandez A, Saul L, Arlt J, Moral $M$, Vendrell M. Tricarbocyanine N-triazoles: the scaffold-of-choice for long-term near-infrared imaging of immune cells in vivo. Chemical Science (Cambridge), 2018, 9(36): 7261-7270

39. Okuda K, Okabe Y, Kadonosono T, Ueno T, Youssif B G M, Kizaka-Kondoh S, Nagasawa H. 2-Nitroimidazole-tricarbocyanine conjugate as a near-infrared fluorescent probe for in vivo imaging of tumor hypoxia. Bioconjugate Chemistry, 2012, 23(3): 324-329

40. Cosco E D, Caram J R, Bruns O T, Franke D, Day R A, Farr E P, Bawendi M G, Sletten E M. Flavylium polymethine fluorophores for near- and shortwave infrared imaging. Angewandte Chemie International Edition, 2017, 56(42): 13126-13129

41. Benson S, Fernandez A, Barth N D, de Moliner F, Horrocks M H, Herrington C S, Abad J L, Delgado A, Kelly L, Chang Z, et al. SCOTfluors: small, conjugatable, orthogonal, and tunable fluorophores for in vivo imaging of cell metabolism. Angewandte Chemie International Edition, 2019, 58(21): 6911-6915

42. Yun S W, Kang N Y, Park S J, Ha H H, Kim Y K, Lee J S, Chang Y T. Diversity oriented fluorescence library approach (DOFLA) for live cell imaging probe development. Accounts of Chemical Research, 2014, 47(4): 1277-1286

43. Lee J S, Vendrell M, Chang Y T. Diversity-oriented optical imaging probe development. Current Opinion in Chemical Biology, 2011, 15(6): 760-767

44. Luo X, Qian L J, Xiao Y S, Tang Y, Zhao Y, Wang X, Gu L Y, Lei Z $\mathrm{H}$, Bao J M, Wu J H, et al. A diversity-oriented rhodamine library for wide-spectrum bactericidal agents with low inducible resistance against resistant pathogens. Nature Communications, 2019, 10(1): $1-12$

45. Burchak O N, Mugherli L, Ostuni M, Lacapere J J, Balakirev M Y. Combinatorial discovery of fluorescent pharmacophores by multicomponent reactions in droplet arrays. Journal of the American Chemical Society, 2011, 133(26): 10058-10061

46. Kaplan J, Ward D M. The essential nature of iron usage and regulation. Current Biology, 2013, 23(15): R642-R646

47. Dev S, Babitt J L. Overview of iron metabolism in health and disease. Hemodialysis International. International Symposium on Home Hemodialysis, 2017, 21: S6-S20

48. Trivedi P C, Bartlett J J, Pulinilkunnil T. Lysosomal biology and function: modern view of cellular debris bin. Cells, 2020, 9(5): $1131-1166$

49. Xu H, Ren D. Lysosomal physiology. Annual Review of Physiology, 2015, 77(1): 57-80 